\title{
The consumption of coffee and black tea and the risk of lung cancer
}

\author{
Romain Pasquet ${ }^{1,2}$ \\ Igor Karp ${ }^{1,3}$ \\ Jack Siemiatycki ${ }^{1,2}$ \\ Anita Koushik*1,2
}

\begin{abstract}
Affiliations:
1 Département de médecine sociale et préventive, Université de Montréal, Montréal, Canada

2 Université de Montréal Hospital Research Centre (CRCHUM), Montréal, Canada

3 Department of Epidemiology and Biostatistics, Schulich School of Medicine and Dentistry, University of Western Ontario, London, Canada
\end{abstract}

Running title: Coffee, tea and lung cancer risk

*Correspondence to: Dr. Anita Koushik, Université de Montréal Hospital Research Centre (CRCHUM), 850 Saint-Denis Street, 2nd Floor, Montreal, Quebec H2X 0A9, Canada (Tel: 514890-8000 ext. 15915; Fax: 514-412-7018; e-mail: anita.koushik@umontreal.ca).

Conflicts of interest: None declared

Word count: 3,314

Abstract word count: 187

This is the post-print version of the following article published in Annals of Epidemiology:

Pasquet R, Karp I, Siemiatycki J, Koushik A. Intake of black tea and coffee and the risk of lung cancer. Ann Epidemiol 2016;26(11):757-763.e2.

The electronic version of the article is available at:

http://dx.doi.org/10.1016/j.annepidem.2016.09.001 


\begin{abstract}
Purpose

Coffee and black tea are among the most consumed beverages worldwide. While their potential role in lung cancer occurrence has been investigated in several studies, results have been inconclusive. We investigated the associations between intake of coffee and black tea with lung cancer in a population-based case-control study in Montreal, Canada.
\end{abstract}

\title{
Methods
}

These analyses included 1,130 cases and 1,483 controls. Adjusted odds ratios (OR) were estimated between four metrics of coffee and black tea consumption (frequency, average daily amount, duration, and cumulative amount) and lung cancer, using unconditional logistic regression.

\section{Results}

The adjusted ORs (95\% confidence intervals) for lung cancer comparing daily to never consumers were $0.73(0.49-1.10)$ for coffee and $1.05(0.85-1.31)$ for black tea. Analyses of other metrics did not reveal any clear patterns of increasing or decreasing risk with increasing amounts or duration of consumption. There was no strong evidence of OR modification by sex or smoking level. The OR estimates did not materially differ by histological subtype for either of the beverages.

\section{Conclusion}

Our results do not provide strong support for associations between consumption of coffee and black tea and lung cancer.

List of abbreviations: OR (odds ratio), CI (confidence interval), CSI (comprehensive smoking indicator)

Keywords: Coffee, tea, lung neoplasms, epidemiology, case-control studies, risk factors 


\section{Introduction}

Coffee and tea, which are consumed worldwide by billions of individuals, may contribute to lung cancer risk. Both beverages are composed of hundreds of chemicals, some of which may reduce risk while others may increase it. For instance, catechins, found in tea, and chlorogenic acid, present in coffee, are antioxidants that could reduce lung cancer risk (1-4). Caffeine, present in both coffee and tea, could increase risk via activation of proteins involved in various regulatory signal transduction pathways (5).

In a systematic review of the literature published through 2006, the available evidence on the associations between consumption of coffee and tea and lung cancer was judged to be limited and inconclusive (6). In two subsequently published meta-analyses $(7,8)$, the evidence was consistent with no association between black tea consumption and lung cancer, though in one of these, statistically significant heterogeneity between studies was reported (7). In subsequently published meta-analyses (8-11) and individual studies $(12,13)$ of coffee intake, positive associations were reported in all but one individual study (11); statistically significant heterogeneity between studies was reported in two of the meta-analyses $(9,10)$.

Residual confounding by smoking may have affected the results in some studies of both coffee and black tea. For instance, in two of the meta-analyses that reported positive associations with coffee consumption, inverse associations were suggested among never smokers $(9,10)$. Also, only a few studies (14-17) have adjusted for occupational exposure to lung carcinogens, one of the most important lung cancer risk factors after smoking (18). Furthermore, lifetime duration of consumption of these beverages might be an important aspect in the association with lung cancer risk, but to our knowledge only one study has examined duration (16).

In the context of a large population-based case-control study of lung cancer carried out in Montreal, Canada, we examined the association between coffee and black tea consumption and 
lung cancer risk overall, by sex and smoking level, as well as separately according to histological subtype.

\section{Material and methods}

\section{Study population}

The design of the study has been described previously (19). Briefly, participants were recruited from 1996 to 2001 and included Canadian citizens aged 35 to 75 years who resided in the greater Montreal area. Incident lung cancer cases were identified in the 18 major hospitals serving the study region, and controls were selected from the Quebec voter registration list and frequency matched to the cases by 5 -year age group and sex. The response rate was $85 \%$ among cases and $69 \%$ among controls. The current analysis was limited to participants with complete information on their consumption of either coffee or tea, and on their smoking habits ( $\mathrm{n}=1,111$ cases and 1,469 controls in the analysis of tea, and 1,009 cases and 1,434 controls in the analysis of coffee). Written informed consent was obtained from participants, and the study was approved by the Institutional Review Boards of participating universities and hospitals.

\section{Data collection}

Study participants or their proxies (for 389 cases and 103 controls) participated in a faceto-face interview that was divided into two parts. The first part was a structured section during which data on socio-demographic characteristics (including ethnic group and highest level of schooling) and lifestyle (including coffee and tea intake, alcohol intake, other dietary factors, smoking, and physical activities) were collected. In the second part, a detailed description of lifetime occupational history was collected (19). Participants' occupational histories were subsequently assessed by expert chemists and industrial hygienists to determine lifetime 
occupational exposure to a list of nearly 300 agents (20-23). Family income was represented by the median family income level for the census tract the participant lived in at the time of interview.

For tea and coffee consumption, participants were first asked if they drank the beverage at least once a week and if yes, they were then asked if they drank it nearly every day. For participants who reported drinking the beverage nearly every day, further questions were asked that assessed the age at which they started and stopped consumption, as was the average daily amount consumed (in cups) during the time that they were consumers. The specific type of tea consumed was not assessed, however, in the birth cohort of our participants (most born around 1920-1950), lifetime tea consumption was predominantly black tea. Black tea has historically been the dominant type consumed in North America (24); in Canada, significant green tea importation began only in the late 1990s (reaching 17\% of total tea imported in 2009 (25)). Similarly, our questionnaire did not differentiate between caffeinated and decaffeinated coffee; however, only around 8\% of coffee consumed in Canada in 2010 was decaffeinated (26) and this proportion was likely much lower in the past. Thus, coffee consumption in our study population likely represents primarily caffeinated consumption.

\section{Study variables}

Four metrics were used to summarize lifetime coffee and black tea consumption including: 1) frequency of consumption; 2) average daily amount; 3) duration of consumption and; 4) cumulative amount. For frequency of consumption, participants were categorized as 'never' consumers if they reported not drinking coffee/black tea at least once per week during their life; 'weekly, not daily' consumers if they reported drinking coffee/black tea at least once per week but not nearly every day; and 'daily' consumers if they reported drinking coffee/black 
tea nearly every day. Among 'daily' consumers, categorical variables of average daily amount of consumption, duration of consumption, and cumulative consumption, which incorporated measures of both daily amount and duration of consumption, were defined. Duration of consumption was calculated by subtracting the age at which participants started consuming the beverage from the age at which they stopped. To minimize the risk of reverse-causality bias, consumption during the two years preceding the diagnosis date for cases or the interview date for controls were not included in the calculation of duration of consumption.

Data on consumption of wine was collected in a similar manner to that of coffee and black tea intake, and represented by a categorical variable. Lifetime history of cigarette smoking was represented by the comprehensive smoking index (CSI) (27), which is a continuous variable that incorporates information on smoking status, duration of smoking, time since the cessation of smoking, and average daily intensity of smoking. Exposure to seven known occupational lung carcinogens (asbestos, crystalline silica, chromium VI compound, nickel compounds, benzo(a)pyrene, cadmium compounds and diesel engine emissions) was represented by a categorical variable defining participants as never exposed, exposed to at least one of the seven carcinogens but only at non-substantial levels or exposed to at least one of the seven carcinogens at substantial levels. For a given occupational carcinogen, substantial exposure was defined as exposure to a medium or high level concentration for at least 5 years and for at least 2 hours per week, while non-substantial exposure was defined as exposure to a low concentration and/or shorter duration of exposure. Categorical variables were used to represent ethnic group and number of years of schooling. Family income was represented by tertiles. 


\section{Statistical analysis}

The distribution of study variables was examined by case/control status. To assess the association between each metric of coffee or black tea consumption and lung cancer, odds ratios $(\mathrm{OR})$ and $95 \%$ confidence intervals $(\mathrm{CI})$ were estimated using unconditional logistic regression. Multivariable models included the frequency matching variables (age and sex) and covariates that were identified a priori based on their known association with lung cancer: ethnicity, family income (from median of census tract), years of education, smoking (CSI), and occupational exposure to lung carcinogens. Each model was also adjusted for respondent status (self/proxy). In addition, we considered potential confounding by exposure to other dietary variables (i.e. fruits and vegetables, wine, beer, and spirits), by entering each variable individually and retaining the variable if the OR changed by at least $10 \%$. Only the variable for wine intake was retained and in 9 cases and 2 controls with missing values, the modal value among controls (never drinker) was used

Modification of the ORs for coffee or black tea consumption and lung cancer risk by sex or by smoking level was evaluated by including in the models product terms for the consumption metric and the potential effect modifier. The p-value for multiplicative interaction was based on the likelihood ratio test comparing the models with and without the product terms. Smoking level was categorized as never, light, and heavy, where light smoking and heavy smoking were defined based on dichotomizing at the median CSI value (1.928) among all ever-smokers in the study population. Because there were few cases in the never-smoking category (47 cases), neversmoking and light-smoking were combined into one category. Within each level of smoking, models were still adjusted for the continuous CSI variable.

We examined associations with histological subtype by conducting separate analyses based on the cases of a specified histological subtype and all controls. In sensitivity analyses, 
analyses were restricted to self-respondents to assess the potential for information bias due to potentially poorer quality of recall by proxy respondents relative to self-respondents. We also conducted analyses where consumption of coffee or black tea during the 20 years prior to diagnosis or interview was not included in the exposure definition in order to examine associations with exposures restricted to the operational induction period of lung cancer.

\section{Results}

The majority of participants were male and over 65 years old (table I). Adenocarcinoma and squamous cell carcinoma were the most common histological subtypes of lung cancer. Compared to controls, cases were more likely to be represented by a proxy respondent during the interview, to be French Canadian, to have had fewer years of schooling, to have a lower family income, to be an ever-smoker, to have consumed less wine, and to have been exposed to the selected occupational carcinogens.

For black tea consumption, there was no strong pattern of association between frequency of consumption and lung cancer risk, nor for the quantitative metrics of daily consumption (table II). For daily coffee consumption an OR estimate of 0.73 was observed in the fully adjusted models, but the confidence limits did not exclude 1.0, while for weekly, but not daily coffee consumption, the OR was lower and statistically significant (table III). None of the quantitative metrics of daily coffee consumption indicated a monotonic dose-response pattern. However, compared to never drinking coffee, the lowest categories of amount of daily coffee consumption and lowest category of cumulative consumption indicated statistically significant lower risks of lung cancer, but OR estimates were virtually null for the highest intake categories for these variables. Differences observed between the age-/sex-adjusted versus fully-adjusted OR estimates were mainly due to confounding by smoking (results not shown). Similar results were observed 
for all metrics of coffee and black tea consumption when excluding the last 20 years of consumption from the exposure definition, and by restricting the analyses to self-respondents (results not shown). When examining the joint effects of 'never' vs. 'ever' consumption of tea and coffee intake, the results were too imprecise to allow discrimination between the hypotheses of presence or absence of multiplicative interaction (results not shown).

Associations between black tea and coffee consumption and lung cancer did not statistically significantly differ by sex or by smoking level (all p-values for multiplicative interaction were greater than 0.05) (appendix tables A.I and A.II). The results according to histological type were very imprecise (table IV), with four of the tested associations being statistically significant (i.e, for $>50$ years of black tea consumption and adenocarcinoma $(\mathrm{OR}=1.60)$, for $>2$ cups/day of black tea for $\leq 40$ years and squamous cell carcinoma $(\mathrm{OR}=2.18)$, and for weekly but not daily consumption of coffee with both squamous cell carcinoma and small cell carcinoma $(\mathrm{ORs}=0.33$ and 0.10 , respectively).

\section{Discussion}

In this large population-based case-control study, we did not observe evidence for an association between black tea consumption, defined according to frequency, amount, duration, and cumulative consumption, and lung cancer overall, nor subgroups defined by sex or level of smoking. For coffee consumption, there was evidence of a lower risk of lung cancer among weekly but not daily consumers compared to never consumers. Similarly, there was some evidence that lower coffee intakes defined by average daily amounts and cumulative consumption may be associated with lower risks. The associations between coffee intake and lung cancer did not vary significantly by sex or smoking level. While some statistically significant associations with certain metrics of coffee or black tea intake were observed for 
different histological types, in general the estimated ORs did not vary appreciably across histological subtypes of lung cancer.

In previous research, five cohort studies $(13,28-31)$ and 14 case-control studies $(14,15$, $17,32-42)$ have examined lung cancer risk in relation to black tea consumption $(15,30,31,40-$ 42) or tea consumption in countries where black tea was the predominant type consumed $(13,14$, 17, 28, 29, 32-39). Findings have been inconsistent with studies having reported positive (14, 17, $31,37-39,42)$, inverse $(29,31,32,34-36,41,42)$ and null $(13,15,28,30,33,40-42)$ associations for increasing intakes in populations of men only, women only and/or men and women together. Of those results that were statistically significant, three (37-39) suggested a positive association and six $(29,32,35,36,41,42)$ suggested an inverse association.

For coffee intake, eight cohort studies $(12,13,31,43-47)$ and 14 case-control studies (14$17,33-39,42,48,49)$ have previously reported associations with lung cancer. Out of 30 relative risks for increasing coffee intakes reported for men only, women only and/or both men and women across these 22 studies, 17 were in the positive direction $(12-15,31,33,34,38,39$, 4449), which was statistically significant in eight $(12-15,38,45,46,48)$. Among the other results, the majority were near the null value, with only two having reported relative risk estimates of 0.5 or less $(17,48)$, which were not statistically significant.

Our results for black tea consumption do not provide strong evidence of an association with lung cancer risk. Tea has been hypothesized to reduce lung cancer risk because of its high concentration of catechins, an antioxidant (3). However, the principal catechins found in black tea are theaflavin and thearubigen, which are oxidized forms of catechins and less bioavailable (4). Thus, our findings, as well as that of others, may reflect the fact that the antioxidative properties of black tea are relatively weak. It is also possible that consumption habits such as beverage size, brewing time, quantity of black tea in a cup or the use of additives resulted in 
antioxidant concentrations that were too small for an effect on lung cancer risk. We were unable to examine these factors, as they were not measured.

For coffee consumption and lung cancer, we observed a statistically significantly inverse association with weekly consumption, but not with daily consumption. Our findings for average daily amount of coffee consumed and cumulative consumption were consistent with this lower relative risk at lower intakes, which then shifts towards the null at higher intakes. Coffee is a complex substance composed of hundreds of chemicals including antioxidants $(1,2)$, which could prevent cancer, as well as caffeine which has been shown to promote lung cancer proliferation (5) and inhibit the effects of antioxidants (50). Our observation of inverse associations only with lower consumption (i.e., presumably lower caffeine intake compared to daily/higher consumption) may reflect the possibility that at higher amounts of coffee consumption, any positive effect of antioxidants may be counterbalanced by a carcinogenic effect of caffeine in coffee. In five previous studies that specifically assessed decaffeinated coffee (12, $13,15,33,39)$, strong inverse associations with lung cancer were reported in three $(15,33,39)$, supporting the notion that coffee contains potentially cancer preventive properties. Furthermore, in studies of caffeinated coffee where the reference category included low consumers $(15,45,46$, 48), rather than an 'unexposed' group of non-drinkers, the observed statistically significant positive associations support the notion that increasing caffeine intakes might increase risk, and thus possibly mask any protective effects of other components of coffee. Interestingly, one study (49) reported a similar pattern of association, with a statistically significant lower risk at the lowest level of consumption vs. non-drinkers but a non-significant higher risk at the highest consumption. On the other hand, the non-monotonic relation with coffee intake suggested in our study may reflect chance. 
A fairly unique aspect of our study was our ability to examine risk as a function of duration of intake. Only one other study analyzed duration of coffee consumption and, similar to us, observed no statistically significant association with lung cancer (16). Our findings for different histological types were consistent with the relatively few studies of black tea $(15,36$, $42)$ and coffee consumption $(12,15-17,36,42,48)$ that reported no significant differences in the strength or direction of the associations for different histological subtypes of lung cancer.

Cases and controls were identified from the same study base, the identification of participants was independent of coffee or black tea, and the participation rates were quite high, thus minimizing the potential for selection bias. With 1,130 cases and 1,483 controls overall, we were able to explore differences by histological subtype and potential effect modification by sex and smoking. Nonetheless, these results were characterized by a high degree of statistical imprecision. Also, detailed information on frequency and duration of consumption was not collected for 'weekly, not daily' consumers thus limiting the number of participants included in analyses of metrics based on these variables.

A major strength of our study was the detailed assessment of smoking history, the most important potential confounder in our study. In particular, we adjusted for the CSI, a metric that was previously developed and validated by our team (27) and that incorporates, in an optimal manner, the key lung cancer-relevant aspects of cigarette-smoking history, including total duration of cigarette smoking, the average smoking intensity, and time since cessation. Furthermore, the detailed assessment of occupational history along with expert assessment of lung carcinogen exposure allowed for high quality control for potential confounding by the most important occupational lung carcinogens. Nonetheless, the weak inverse association we observed for weekly coffee intake may reflect confounding by unobserved confounding factors and/or residual confounding due to incomplete control for observed confounding factors. Prospective studies with 
multiple assessments of exposures and covariates may reduce residual confounding due to error in measurement of observed confounders, while the effect of unobserved confounders can be addressed in instrumental variable-based designs $(51,52)$.

Our questionnaire assessed coffee and tea over the lifetime, in contrast to traditional food frequency questionnaires, which generally provides a measure of usual intake of various foods and beverages over a relatively recent period of time (such as past month or past year) (53). Thus, our assessment allowed us to have an estimate of lifetime intake which is particularly important in a study of cancer etiology as lifetime intake is more likely to better capture periods of etiologic relevance than current or very recent intake. Nonetheless, recall over a long period may contribute to misclassification of exposure, though studies have shown that intake of coffee and other dietary factors can be reliably and validly reported $(54,55)$, especially when intervieweradministered (56), as was the case in our study. Another potential source of non-differential misclassification of exposure is the absence of information on factors that may affect the concentration of relevant chemical components in the beverage (e.g. brewing time). The use of proxy respondents for some participants also may have resulted in exposure misclassification because of possible lower quality data, although our findings did not appreciably differ upon restricting the analysis to self-respondents.

In summary, our results do not provide strong support for an association between consumption of coffee or black tea and lung cancer. For coffee, our results are suggestive that low consumption may decrease the risk of lung cancer. Research that includes more detailed information on these beverages, including specific components of these beverages such as caffeine, may offer further insight. 


\section{Acknowledgements}

Ms. Lesley Richardson supervised the fieldwork for the study. The authors are grateful to Ms. Lesley Richardson and Ms. Sally Campbell for editorial assistance.

Financial Support: This research was funded by the Canadian Cancer Society (grant \#19912) and the Canadian Institutes of Health Research (grant \#14704). The sponsors did not play any role in the study design; the collection, analysis and interpretation of data; in the writing of this article; nor in the decision to submit the article for publication. AK was supported by a New Investigator Award from the Canadian Institutes of Health Research. JS holds a Canada Research Chair in Environmental Epidemiology and Population Health and the Guzzo Chair in Environment and Cancer. 


\section{References}

1. Rajavelu A, Tulyasheva Z, Jaiswal R, Jeltsch A, Kuhnert N. The inhibition of the mammalian DNA methyltransferase 3a (Dnmt3a) by dietary black tea and coffee polyphenols. BMC Biochem 2011;12:16.

2. Serafini M, Testa MF. Redox ingredients for oxidative stress prevention: the unexplored potentiality of coffee. Clin Dermatol 2009;27(2):225-9.

3. Singh BN, Shankar S, Srivastava RK. Green tea catechin, epigallocatechin-3-gallate (EGCG): mechanisms, perspectives and clinical applications. Biochem Pharmacol 2011;82(12):1807-21.

4. Yang CS, Wang H. Mechanistic issues concerning cancer prevention by tea catechins. Mol Nutr Food Res 2011;55(6):819-31.

5. Al-Wadei HA, Takahashi T, Schuller HM. Caffeine stimulates the proliferation of human lung adenocarcinoma cells and small airway epithelial cells via activation of PKA, CREB and ERK1/2. Oncol Rep 2006;15(2):431-5.

6. World Cancer Research Fund/American Institute for Cancer Research. Food, Nutrition, Physical Activity and the Prevention of Cancer: a Global Perspective, Washington, DC: AICR, 2007.

7. Tang NP, Wu YM, Zhou B, Wang B, Yu RB. Green tea, black tea consumption and risk of lung cancer: A meta-analysis. Lung Cancer 2009;65(3):274-83.

8. Wang YP, Yu XY, Wu YL, Zhang DF. Coffee and tea consumption and risk of lung cancer: A dose-response analysis of observational studies. Lung Cancer 2012;78(2):169-70.

9. Xie Y, Qin J, Nan G, Huang S, Wang Z, Su Y. Coffee consumption and the risk of lung cancer: an updated meta-analysis of epidemiological studies. Eur J Clin Nutr 2016;70:199-206.

10. Tang NP, Wu YM, Ma J, Wang B, Yu RB. Coffee consumption and risk of lung cancer: A meta-analysis. Lung Cancer 2010;67(1):17-22.

11. Yu XF, Bao ZJ, Zou JA, Dong J. Coffee consumption and risk of cancers: a meta-analysis of cohort studies - art. no. 96. BMC Cancer 2011;11(96):15.

12. Guertin KA, Freedman ND, Loftfield E, Graubard BI, Caporaso NE, Sinha R. Coffee consumption and incidence of lung cancer in the NIH-AARP Diet and Health Study. Int J Epidemiol [Epub ahead of print] 2015.

13. Hashibe M, Galeone C, Buys SS, Gren L, Boffetta P, Zhang ZF, et al. Coffee, tea, caffeine intake, and the risk of cancer in the PLCO cohort. Br J Cancer 2015;113(5):809-16. 
14. Ganesh B, Sushama S, Monika S, Suvarna P. A case-control study of risk factors for lung cancer in Mumbai, India. Asian Pac J Cancer Prev 2011;12(2):357-62.

15. Baker JA, McCann SE, Reid ME, Nowell S, Beehler GP, Moysich KB. Associations between black tea and coffee consumption, and risk of lung cancer among current and former smokers. Nutr Cancer 2005;52(1):15-21

16. Sanikini H, Radoi L, Menvielle G, Guida F, Mattei F, Cenee S, et al. Coffee consumption and risk of lung cancer: the ICARE study. Eur J Epidemiol 2015;30(1):81-5.

17. Nyberg F, Agrenius V, Svartengren K, Svensson C, Pershagen G. Dietary factors and risk of lung cancer in never-smokers. Int J Cancer 1998;78(4):430-6.

18. Spyratos D, Zarogoulidis P, Porpodis K, Tsakiridis K, Machairiotis N, Katsikogiannis N, et al. Occupational exposure and lung cancer. J Thorac Dis 2013;5 (Suppl. 4):S440-5.

19. Pintos J, Parent ME, Rousseau MC, Case BW, Siemiatycki J. Occupational exposure to asbestos and man-made vitreous fibers, and risk of lung cancer: Evidence from two case-control studies in Montreal, Canada. J. Occup. Environ. Med 2008;50(11):1273-81.

20. Siemiatycki J. Risk Factors for Cancer in the Workplace. Boca Raton: CRC Press; 1991.

21. Gerin M. Recent approaches to retrospective exposure assessment in occupational cancer epidemiology. Recent Results Cancer Res 1990;120:39-49.

22. Gérin M, Siemiatycki J. The occupational questionnaire in retrospective epidemiologic studies: recent approaches in community-based studies. Appl Occup Environ Hyg 1991;6(6):495501.

23. Stewart PA, Stewart WF, Siemiatycki J, Heineman EF, Dosemeci M. Questionnaires for collecting detailed occupational information for community-based case control studies. Am Ind Hyg Assoc J 1998;59(1):39-44.

24. Weisburger JH. Tea and health: a historical perspective. Cancer Lett 1997;114(1-2):3157.

25. Agriculture and Agri-food Canada. The Canadian Tea Industry 2010. Available from: http://www.agr.gc.ca/eng/industry-markets-and-trade/statistics-and-market-information/byproduct-sector/processed-food-and-beverages/the-canadian-tea-industry/?id=1298047470064; 2014 (accessed 2015.12.05).

26. International Trade Centre. The Coffee Exporter's Guide. 3rd edition. Geneva: International Trade Centre; 2011.

27. Leffondré K, Abrahamowicz M, Xiao Y, Siemiatycki J. Modelling smoking history using a comprehensive smoking index: application to lung cancer. Stat Med. 2006;25(24):4132-46. 
28. Goldbohm RA, Hertog MG, Brants HA, van Poppel G, van den Brandt PA. Consumption of black tea and cancer risk: a prospective cohort study. J Natl Cancer Inst. 1996;88(2):93-100.

29. Hirvonen T, Virtamo J, Korhonen P, Albanes D, Pietinen P. Flavonol and flavone intake and the risk of cancer in male smokers (Finland). Cancer Causes Control. 2001;12(9):789-96.

30. Heilbrun LK, Nomura A, Stemmermann GN. Black tea consumption and cancer risk: a prospective study. Br J Cancer. 1986;54:677-83.

31. Khan MM, Goto R, Kobayashi K, Suzumura S, Nagata Y, Sonoda T, et al. Dietary habits and cancer mortality among middle aged and older Japanese living in Hokkaido, Japan by cancer site and sex. Asian Pac J Cancer Prev. 2004;5(1):58-65.

32. Cui Y, Morgenstern H, Greenland S, Tashkin DP, Mao JT, Cai L, et al. Dietary flavonoid intake and lung cancer - A population-based case-control study. Cancer. 2008;112(10):2241-8.

33. Mettlin C. Milk drinking, other beverage habits, and lung cancer risk. Int J Cancer. 1989;43(4):608-12.

34. Axelsson G, Liljeqvist T, Andersson L, Bergman B, Rylander R. Dietary factors and lung cancer among men in west Sweden. Int J Epidemiol. 1996;25(1):32-9.

35. Hu JF, Mao Y, Dryer D, White K. Risk factors for lung cancer among Canadian women who have never smoked. Cancer Detect Prev. 2002;26(2):129-38.

36. Mendilaharsu M, De Stefani E, Deneo-Pellegrini H, Carzoglio JC, Ronco A. Consumption of tea and coffee and the risk of lung cancer in cigarette-smoking men: a casecontrol study in Uruguay. Lung Cancer. 1998;19(2):101-7.

37. Sankaranarayanan R, Varghese C, Duffy SW, Padmakumary G, Day NE, Nair MK. A case-control study of diet and lung cancer in Kerala, south India. Int J Cancer. 1994;58(5):644-9.

38. Luqman M, Javed MM, Daud S, Raheem N, Ahmad J, Khan AU. Risk factors for lung cancer in the Pakistani population. Asian Pac J Cancer Prev. 2014;15(7):3035-9.

39. Mohr DL, Blot WJ, Tousey PM, Van Doren ML, Wolfe KW. Southern cooking and lung cancer. Nutr Cancer. 1999;35(1):34-43.

40. Le Marchand L, Murphy SP, Hankin JH, Wilkens LR, Kolonel LN. Intake of flavonoids and lung cancer. J Natl Cancer Inst. 2000;92(2):154-60.

41. Ohno Y, Wakai K, Genka K, Ohmine K, Kawamura T, Tamakoshi A, et al. Tea consumption and lung cancer risk: a case-control study in Okinawa, Japan. Jpn J Cancer Res. 1995;86(11):1027-34. 
42. Kubik A, Zatloukal P, Tomasek L, Dolezal J, Syllabova L, Kara J, et al. A case-control study of lifestyle and lung cancer associations by histological types. Neoplasma. 2008;55(3):1929.

43. Takezaki T, Inoue M, Kataoka H, Ikeda S, Yoshida M, Ohashi Y, et al. Diet and lung cancer risk from a 14-year population-based prospective study in Japan: with special reference to fish consumption. Nutr Cancer. 2003;45(2):160-7.

44. Bae JM, Li ZM, Shin MH, Kim DH, Lee MS, Ahn YO. Pulmonary Tuberculosis and Lung Cancer Risk in Current Smokers: The Seoul Male Cancer Cohort Study. J Korean Med Sci. 2013;28(6):896-900.

45. Stensvold I, Jacobsen BK. Coffee and cancer - a prospective study of 43,000 Norwegian men and women. Cancer Causes Control. 1994;5(5):401-8.

46. Chow WH, Schuman LM, McLaughlin JK, Bjelke E, Gridley G, Wacholder S, et al. A cohort study of tobacco use, diet, occupation, and lung cancer mortality. Cancer Causes Control. 1992;3(3):247-54.

47. Nomura A, Heilbrun LK, Stemmermann GN. Prospective study of coffee consumption and the risk of cancer. J Natl Cancer Inst. 1986;76(4):587-90.

48. Takezaki T, Hirose K, Inoue M, Hamajima N, Yatabe Y, Mitsudomi T, et al. Dietary factors and lung cancer risk in Japanese: with special reference to fish consumption and adenocarcinomas. Br J Cancer. 2001 May 4;84(9):1199-206.

49. Chiu YL, Wang XR, Qiu H, Yu ITS. Risk factors for lung cancer: a case-control study in Hong Kong women. Cancer Causes Control. 2010;21(5):777-85.

50. O'Prey J, Brown J, Fleming J, Harrison PR. Effects of dietary flavonoids on major signal transduction pathways in human epithelial cells. Biochem Pharmacol. 2003;66(11):2075-88.

51. Martens EP, Pestman WR, de Boer A, Belitser SV, Klungel OH. Instrumental variables: application and limitations. Epidemiology. 2006;17(3):260-7.

52. Smith GD, Ebrahim S. Mendelian randomization: prospects, potentials, and limitations. Int J Epidemiol. 2004 Feb;33(1):30-42.

53. Freudenheim JL. A review of study designs and methods of dietary assessment in nutritional epidemiology of chronic disease. J Nutr. 1993;123(Suppl. 2):401-5.

54. James JE, Bruce MS, Lader MH, Scott NR. Self-report reliability and symptomatology of habitual caffeine consumption. Br J Clin Pharmacol. 1989;27(4):507-14.

55. Fraser GE, Lindsted KD, Knutsen SF, Beeson WL, Bennett H, Shavlik DJ. Validity of dietary recall over 20 years among California Seventh-day Adventists. Am J Epidemiol. 1998;148(8):810-8. 
56. Sobell J, Block G, Koslowe P, Tobin J, Andres R. Validation of a retrospective questionnaire assessing diet 10-15 years ago. Am J Epidemiol. 1989;130(1):173-87. 
Table I. Characteristics of the study participants

\begin{tabular}{|c|c|c|}
\hline & $\begin{array}{c}\text { Cases, } N=1,130 \\
n(\%)\end{array}$ & $\begin{array}{c}\text { Controls, } N=1,483 \\
\text { n (\%) }\end{array}$ \\
\hline \multicolumn{3}{|l|}{ Age } \\
\hline$<45$ years & $37(3.3)$ & $52(3.5)$ \\
\hline $45-<55$ years & $164(14.5)$ & $202(13.6)$ \\
\hline $55-<65$ years & $381(33.7)$ & $442(29.8)$ \\
\hline $65-<75$ years & $511(45.2)$ & $745(50.3)$ \\
\hline$\geq 75$ years & $37(3.3)$ & $42(2.8)$ \\
\hline \multicolumn{3}{|l|}{ Sex } \\
\hline Male & 677 (59.9) & 878 (59.2) \\
\hline Female & $453(40.1)$ & $605(40.8)$ \\
\hline \multicolumn{3}{|l|}{ Respondent status } \\
\hline Self & $741(65.6)$ & $1380(93.1)$ \\
\hline Proxy & $389(34.4)$ & $103(6.9)$ \\
\hline \multicolumn{3}{|l|}{ Ethnic group } \\
\hline French Canadian & $876(77.5)$ & $979(66.0)$ \\
\hline English Canadian & $74(6.6)$ & $82(5.5)$ \\
\hline Other & $180(15.9)$ & $422(28.5)$ \\
\hline \multicolumn{3}{|l|}{ Years of schooling } \\
\hline$<7$ & $285(25.1)$ & $312(21.0)$ \\
\hline $7-<12$ & $553(48.9)$ & $563(38.0)$ \\
\hline$\geq 12$ & $292(25.8)$ & $608(41.0)$ \\
\hline \multicolumn{3}{|l|}{ Median census tract family income } \\
\hline Low & $500(44.3)$ & $491(33.1)$ \\
\hline Middle & $369(32.7)$ & $503(33.9)$ \\
\hline High & $261(23.1)$ & $489(33.0)$ \\
\hline \multicolumn{3}{|l|}{ Cigarette smoking } \\
\hline Never & $47(4.2)$ & $460(31.0)$ \\
\hline Ex-smoker & $644(57.0)$ & $690(46.5)$ \\
\hline Current smoker & $439(38.8)$ & $333(22.5)$ \\
\hline $\begin{array}{l}\text { Average amount, cigarettes/year } \\
(\text { median }(\mathrm{IQR}))^{1}\end{array}$ & $1175(773)$ & $775(838)$ \\
\hline $\begin{array}{l}\text { Time since cessation, years (median } \\
(\mathrm{IQR}))^{2}\end{array}$ & $1.2(10.2)$ & $17.7(16.6)$ \\
\hline $\begin{array}{l}\text { Smoking duration, years (median } \\
(\mathrm{IQR}))^{1}\end{array}$ & $43.0(14.4)$ & $33.2(21.1)$ \\
\hline \multicolumn{3}{|l|}{ Wine consumption } \\
\hline Never & $739(65.4)$ & $665(44.8)$ \\
\hline Weekly, not daily & $225(19.9)$ & $545(36.8)$ \\
\hline Daily & $166(14.7)$ & $273(18.4)$ \\
\hline \multicolumn{3}{|l|}{ Exposures to occupational carcinogens ${ }^{3}$} \\
\hline Never exposed & $652(57.7)$ & $935(63.0)$ \\
\hline Non-substantially exposed & $303(26.8)$ & $372(25.1)$ \\
\hline Substantially exposed & $175(15.5)$ & $176(11.9)$ \\
\hline \multicolumn{3}{|l|}{ Histological subtype } \\
\hline Squamous cell carcinoma & $328(29.0)$ & \\
\hline Adenocarcinoma & $443(39.2)$ & \\
\hline Small cell carcinoma & $187(16.6)$ & \\
\hline
\end{tabular}


Table II. Odds ratio estimates for the association between black tea consumption and lung cancer risk $^{1}$

\begin{tabular}{|c|c|c|c|c|}
\hline Consumption metric & $\begin{array}{c}\text { Cases } \\
(\mathrm{N}=1,111) \\
\end{array}$ & $\begin{array}{l}\text { Controls } \\
(\mathrm{N}=1,469)\end{array}$ & $\begin{array}{c}\text { Age and sex adjusted } \\
\text { OR (95\% CI) } \\
\end{array}$ & $\begin{array}{l}\text { Fully adjusted } \\
\text { OR }(95 \% \text { CI })^{2} \\
\end{array}$ \\
\hline \multicolumn{5}{|l|}{ Frequency of consumption } \\
\hline Never $^{3}$ & 551 & 604 & 1.00 (ref) & 1.00 (ref) \\
\hline Weekly, not daily ${ }^{4}$ & 127 & 281 & $0.49(0.39-0.62)$ & $0.78(0.58-1.05)$ \\
\hline Daily & 433 & 584 & $0.83(0.70-0.98)$ & $1.05(0.85-1.31)$ \\
\hline \multicolumn{5}{|c|}{ Average daily amount of consumption ${ }^{5}$} \\
\hline Never $^{3}$ & 551 & 604 & 1.00 (ref) & 1.00 (ref) \\
\hline$\leq 1 \mathrm{cup} /$ day & 128 & 238 & $0.60(0.47-0.76)$ & $0.95(0.70-1.28)$ \\
\hline$>1$ to 2 cups/day & 162 & 219 & $0.84(0.66-1.06)$ & $1.06(0.79-1.42)$ \\
\hline$>2$ cups/day & 143 & 127 & $1.27(0.97-0.99)$ & $1.25(0.90-1.75)$ \\
\hline \multicolumn{5}{|l|}{ Duration of consumption 5} \\
\hline $\mathrm{Never}^{3}$ & 551 & 604 & 1.00 (ref) & 1.00 (ref) \\
\hline$<20$ years & 52 & 61 & $0.89(0.60-1.32)$ & $1.41(0.87-2.29)$ \\
\hline$\geq 20$ to $<30$ years & 39 & 55 & $0.67(0.43-1.04)$ & $0.97(0.57-1.64)$ \\
\hline$\geq 30$ to $<40$ years & 80 & 106 & $0.76(0.56-1.05)$ & $0.98(0.66-1.45)$ \\
\hline$\geq 40$ to $<50$ years & 141 & 203 & $0.81(0.63-1.04)$ & $0.94(0.69-1.28)$ \\
\hline$\geq 50$ years & 121 & 159 & $0.99(0.74-1.31)$ & $1.24(0.87-1.78)$ \\
\hline \multicolumn{5}{|l|}{ Cumulative consumption 5} \\
\hline $\mathrm{Never}^{3}$ & 551 & 604 & 1.00 (ref) & 1.00 (ref) \\
\hline$\leq 40$ years, $\leq 2$ cups/day & 118 & 187 & $0.63(0.49-0.83)$ & $0.97(0.70-1.34)$ \\
\hline$\leq 40$ years, $>2$ cups/day & 53 & 39 & $1.37(0.89-2.12)$ & $1.49(0.88-2.52)$ \\
\hline$>40$ years, $\leq 2$ cups/day & 172 & 270 & $0.77(0.61-0.98)$ & $1.03(0.77-1.38)$ \\
\hline$>40$ years, $>2$ cups/day & 90 & 88 & $1.23(0.89-1.27)$ & $1.14(0.76-1.71)$ \\
\hline
\end{tabular}

1. Only includes participants with complete information on their black tea consumption

2. Adjusted for age, sex, respondent status, smoking (CSI), wine intake (never; weekly, not daily; daily), ethnicity (French Canadian; English Canadian; other), median census tract income (low; medium; high), years of education $(<7 ; 7-<12 ; \geq 12)$ and occupational exposure to carcinogens (Never; non-substantial; substantial)

3. Participants were categorized as never consumers if they reported never consuming black tea at least once per week

4: Participants were categorized as "weekly, not daily" consumers if they reported consuming black tea at least once per week but not nearly every day

5. "Weekly, not daily" consumers not included 
Table III. Odds ratio estimates for the association between coffee consumption and lung cancer risk $^{1}$

\begin{tabular}{|c|c|c|c|c|}
\hline Consumption metric & $\begin{array}{c}\text { Cases } \\
(\mathrm{N}=1,009) \\
\end{array}$ & $\begin{array}{c}\text { Controls } \\
(\mathrm{N}=1,434)\end{array}$ & $\begin{array}{c}\text { Age and sex adjusted } \\
\text { OR (95\% CI) } \\
\end{array}$ & $\begin{array}{l}\text { Fully adjusted } \\
\text { OR }(95 \% \mathrm{CI})^{2} \\
\end{array}$ \\
\hline \multicolumn{5}{|l|}{ Frequency of consumption } \\
\hline Never $^{3}$ & 89 & 88 & 1.00 (ref) & 1.00 (ref) \\
\hline Weekly, not daily ${ }^{4}$ & 32 & 108 & $0.29(0.18-0.48)$ & $0.29(0.16-0.55)$ \\
\hline Daily & 888 & 1238 & $0.71(0.52-0.97)$ & $0.74(0.49-1.10)$ \\
\hline \multicolumn{5}{|l|}{$\begin{array}{l}\text { Average daily amount of } \\
\text { consumption }^{5}\end{array}$} \\
\hline $\mathrm{Never}^{3}$ & 89 & 88 & 1.00 (ref) & 1.00 (ref) \\
\hline$\leq 1 \mathrm{cup} /$ day & 203 & 420 & $0.48(0.34-0.68)$ & $0.69(0.45-1.07)$ \\
\hline$>1$ to 2 cups/day & 224 & 412 & $0.54(0.39-0.76)$ & $0.60(0.39-0.93)$ \\
\hline$>3$ to 4 cups/day & 280 & 295 & $0.94(0.67-1.31)$ & $0.86(0.55-1.33)$ \\
\hline$>4$ cups/day & 181 & 110 & $1.61(1.10-2.35)$ & $1.06(0.65-1.72)$ \\
\hline \multicolumn{5}{|l|}{ Duration of consumption 5} \\
\hline Never $^{3}$ & 89 & 88 & 1.00 (ref) & 1.00 (ref) \\
\hline$<20$ years & 44 & 68 & $0.53(0.32-0.87)$ & $0.71(0.38-1.30)$ \\
\hline$\geq 20$ to $<30$ years & 99 & 134 & $0.57(0.38-0.87)$ & $0.88(0.51-1.50)$ \\
\hline$\geq 30$ to $<40$ years & 223 & 310 & $0.64(0.45-0.91)$ & $0.68(0.43-1.07)$ \\
\hline$\geq 40$ to $<50$ years & 347 & 455 & $0.82(0.59-1.14)$ & $0.76(0.49-1.17)$ \\
\hline$\geq 50$ years & 175 & 271 & $0.78(0.54-1.13)$ & $0.73(0.45-1.18)$ \\
\hline \multicolumn{5}{|l|}{ Cumulative consumption 5} \\
\hline Never $^{3}$ & 89 & 88 & 1.00 (ref) & 1.00 (ref) \\
\hline$\leq 40$ years, $\leq 2$ cups/day & 150 & 318 & $0.42(0.29-0.60)$ & $0.60(0.38-0.94)$ \\
\hline$\leq 40$ years, $>2$ cups/day & 217 & 197 & $0.95(0.66-1.38$ & $0.87(0.54-1.38)$ \\
\hline$>40$ years, $\leq 2 \mathrm{cups} /$ day & 277 & 515 & $0.59(0.42-0.82)$ & $0.68(0.44-1.05)$ \\
\hline$>40$ years, $>2$ cups/day & 244 & 208 & $1.27(0.89-1.81)$ & $0.97(0.61-1.53)$ \\
\hline \multicolumn{5}{|c|}{$\begin{array}{l}\text { 1. Only includes participants with complete information on their coffee consumption } \\
\text { 2. Adjusted for age, sex, respondent status, smoking (CSI), wine intake (never; weekly, not daily; daily), ethnicity (French Canadian; English } \\
\text { Canadian; other), median census tract income (low; medium; high), years of education }(<7 ; 7-<12 ; \geq 12) \text { and occupational exposure to } \\
\text { carcinogens (Never; non-substantial; substantial) } \\
\text { 3. Participants were categorized as never consumers if they reported never consuming coffee at least once per week } \\
\text { 4: Participants were categorized as "weekly, not daily" consumers if they reported consuming coffee at least once per week but not nearly every } \\
\text { day } \\
\text { 5. "Weekly, not daily" consumers not included }\end{array}$} \\
\hline
\end{tabular}


Table IV. Odds ratio estimates of the association between black tea and coffee consumption and lung cancer risk by histological subtype ${ }^{1}$

\begin{tabular}{|c|c|c|c|c|c|c|c|}
\hline \multirow[b]{2}{*}{ Black tea consumption metric ${ }^{3}$} & \multicolumn{3}{|c|}{ OR $(95 \% \mathrm{CI})^{2}$} & \multirow[b]{2}{*}{ Coffee consumption metric ${ }^{4}$} & \multicolumn{3}{|c|}{ OR $(95 \% \mathrm{CI})^{2}$} \\
\hline & $\begin{array}{l}\text { Squamous cell } \\
\text { carcinoma }\end{array}$ & Adenocarcinoma & $\begin{array}{c}\text { Small cell } \\
\text { carcinoma }\end{array}$ & & $\begin{array}{l}\text { Squamous cell } \\
\text { carcinoma }\end{array}$ & Adenocarcinoma & $\begin{array}{c}\text { Small cell } \\
\text { carcinoma }\end{array}$ \\
\hline $\begin{array}{l}\text { Frequency of consumption } \\
\text { Never }^{5} \\
\text { Weekly, not daily } \\
\text { Daily }\end{array}$ & $\begin{array}{c}1.00 \text { (ref) } \\
0.81(0.51-1.29) \\
1.07(0.78-1.48)\end{array}$ & $\begin{array}{c}1.00 \text { (ref) } \\
0.84(0.57-1.25) \\
1.13(0.85-1.51)\end{array}$ & $\begin{array}{c}1.00 \text { (ref) } \\
0.78(0.42-1.43) \\
0.85(0.55-1.30)\end{array}$ & $\begin{array}{l}\text { Frequency of consumption } \\
\text { Never } \\
\text { Weekly, not daily }^{6} \\
\text { Daily }\end{array}$ & $\begin{array}{c}1.00 \text { (ref) } \\
0.32(0.13-0.83) \\
0.83(0.46-1.49)\end{array}$ & $\begin{array}{c}1.00(\mathrm{ref}) \\
0.50(0.22-1.10) \\
0.93(0.54-1.59)\end{array}$ & $\begin{array}{c}1.00 \text { (ref) } \\
0.10(0.02-0.50) \\
0.65(0.32-1.33)\end{array}$ \\
\hline $\begin{array}{l}\text { Average daily amount of consumption } 7 \\
\text { Never }^{5} \\
\leq 1 \text { cup/day } \\
>1 \text { to } 2 \text { cups/day } \\
>2 \text { cups/day }\end{array}$ & $\begin{array}{c}1.00(\mathrm{ref}) \\
0.78(0.49-1.23) \\
1.15(0.75-1.76) \\
1.48(0.93-2.34)\end{array}$ & $\begin{array}{c}1.00 \text { (ref) } \\
0.99(0.67-1.48) \\
1.15(0.78-1.68) \\
1.39(0.90-2.15)\end{array}$ & $\begin{array}{c}1.00(\mathrm{ref}) \\
0.82(0.46-1.49) \\
0.60(0.32-1.12) \\
1.32(0.70-2.48)\end{array}$ & $\begin{array}{l}\text { Average daily amount of consumption } \\
\text { Never } \\
\leq 1 \text { cup/day } \\
>1 \text { to } 2 \text { cups/day } \\
>2 \text { to } 4 \text { cups/day } \\
>4 \text { cups/day }\end{array}$ & $\begin{array}{c}1.00(\mathrm{ref}) \\
0.72(0.38-1.38) \\
0.70(0.37-1.33) \\
0.95(0.50-1.80) \\
1.25(0.62-2.52)\end{array}$ & $\begin{array}{c}1.00(\mathrm{ref}) \\
0.82(0.46-1.48) \\
0.75(0.42-1.35) \\
1.24(0.69-2.21) \\
1.15(0.60-2.18)\end{array}$ & $\begin{array}{c}1.00(\mathrm{ref}) \\
0.64(0.29-1.42) \\
0.46(0.21-1.04) \\
0.68(0.31-1.49) \\
1.05(0.45-2.45)\end{array}$ \\
\hline $\begin{array}{l}\text { Duration of consumption } \\
\quad \text { Never }^{5} \\
\quad<30 \text { years } \\
\geq 30 \text { to }<40 \text { years } \\
\geq 40 \text { to }<50 \text { years } \\
\quad \geq 50 \text { years }\end{array}$ & $\begin{array}{c}1.00(\mathrm{ref}) \\
1.27(0.73-2.21) \\
1.22(0.69-2.14) \\
0.98(0.64-1.52) \\
1.01(0.60-1.68)\end{array}$ & $\begin{array}{c}1.00(\mathrm{ref}) \\
1.15(0.71-1.85) \\
1.12(0.68-1.85) \\
0.89(0.58-1.36) \\
1.60(1.01-2.52)\end{array}$ & $\begin{array}{c}1.00(\mathrm{ref}) \\
1.13(0.55-2.30) \\
0.74(0.33-1.68) \\
0.70(0.38-1.29) \\
0.92(0.45-1.91)\end{array}$ & $\begin{array}{l}\text { Duration of consumption } \\
\text { Never } \\
\quad<30 \text { years } \\
\quad \geq 30 \text { to }<40 \text { years } \\
\geq 40 \text { to }<50 \text { years } \\
\quad \geq 50 \text { years }\end{array}$ & $\begin{array}{c}1.00(\mathrm{ref}) \\
0.80(0.37-1.71) \\
0.91(0.46-1.77) \\
0.88(0.47-1.65) \\
0.68(0.34-1.36)\end{array}$ & $\begin{array}{c}1.00(\mathrm{ref}) \\
1.14(0.60-2.19) \\
0.90(0.50-1.64) \\
0.88(0.49-1.58) \\
0.91(0.48-1.75)\end{array}$ & $\begin{array}{c}1.00(\mathrm{ref}) \\
0.50(0.19-1.30) \\
0.59(0.26-1.34) \\
0.71(0.33-1.54) \\
0.73(0.30-1.80)\end{array}$ \\
\hline $\begin{array}{l}\text { Cumulative consumption } 7 \\
\text { Never } \\
\leq 40 \text { years, } \leq 2 \text { cups/day } \\
\leq 40 \text { years, }>2 \text { cups/day } \\
>40 \text { years, } \leq 2 \text { cups/day } \\
>40 \text { years, }>2 \text { cups/day }\end{array}$ & $\begin{array}{c}1.00(\mathrm{ref}) \\
0.99(0.61-1.60) \\
2.18(1.07-4.46) \\
0.93(0.61-1.43) \\
1.20(0.70-2.08) \\
\end{array}$ & $\begin{array}{c}1.00(\mathrm{ref}) \\
1.01(0.67-1.54) \\
1.61(0.83-3.15) \\
1.11(0.76-1.64) \\
1.28(0.75-2.17) \\
\end{array}$ & $\begin{array}{c}1.00(\mathrm{ref}) \\
0.80(0.42-1.52) \\
1.55(0.55-4.38) \\
0.64(0.35-1.17) \\
1.22(0.59-2.56) \\
\end{array}$ & $\begin{array}{l}\text { Cumulative consumption }^{7} \\
\quad \text { Never }^{5} \\
\leq 40 \text { years, } \leq 2 \text { cups/day } \\
\leq 40 \text { years, }>2 \text { cups/day } \\
>40 \text { years, } \leq 2 \text { cups/day } \\
>40 \text { years, }>2 \text { cups/day }\end{array}$ & $\begin{array}{c}1.00(\mathrm{ref}) \\
0.74(0.37-1.48) \\
0.97(0.48-1.94) \\
0.69(0.37-1.30) \\
1.09(0.56-2.11) \\
\end{array}$ & $\begin{array}{c}1.00(\mathrm{ref}) \\
0.73(0.39-1.35) \\
1.34(0.72-2.49) \\
0.84(0.47-1.53) \\
1.15(0.62-2.15) \\
\end{array}$ & $\begin{array}{c}1.00(\mathrm{ref}) \\
0.51(0.21-1.21) \\
0.62(0.27-1.44) \\
0.57(0.26-1.27) \\
0.99(0.44-2.23) \\
\end{array}$ \\
\hline
\end{tabular}

$1 . \mathrm{n}=322$ cases of squamous cell carcinoma, 438 cases of adenocarcinoma and 183 cases of small cell carcinoma

2. Adjusted for age, sex, respondent status, smoking (CSI), wine intake (never; weekly, not daily; daily), ethnicity (French Canadian; English Canadian; other), median census tract income (low;

medium; high), years of education $(<7 ; 7-<12 ; \geq 12)$ and occupational exposure to carcinogens (Never; non-substantial; substantial)

/drug effects/physiology $</$ keyword $><$ keyword $>$ Signal Transduction/*drug effects/physiology4. Only includes participants with complete information on their coffee consumption

4. Only includes participants with complete information on their coffee consumption

5. Participants were categorized as never consumers if they reported never consuming black tea/coffee at least once per week

6: Participants were categorized as "weekly, not daily" consumers if they reported consuming black tea/coffee at least once per week but not nearly every day

7. "Weekly, not daily" consumers not included 
Appendix table A.I. Odds ratio estimates for the association between black tea consumption and lung cancer risk, by sex and by smoking level ${ }^{1}$

\begin{tabular}{|c|c|c|c|c|}
\hline \multirow{2}{*}{ Consumption metric } & \multicolumn{2}{|c|}{ OR $\left(95 \%\right.$ CI) by sex ${ }^{2}$} & \multicolumn{2}{|c|}{ OR (95\% CI) by smoking level ${ }^{3}$} \\
\hline & Males & Females & Never/light smokers & Heavy smokers \\
\hline \multicolumn{5}{|l|}{ Frequency of consumption } \\
\hline Never ${ }^{4}$ & 1.00 (ref) & 1.00 (ref) & 1.00 (ref) & 1.00 (ref) \\
\hline Weekly, not daily ${ }^{5}$ & $0.88(0.60-1.31)$ & $0.66(0.40-1.09)$ & $0.79(0.53-1.19)$ & $0.82(0.51-1.32)$ \\
\hline Daily & $1.10(0.84-1.45)$ & $0.98(0.67-1.44)$ & $1.08(0.80-1.46)$ & $1.02(0.74-1.41)$ \\
\hline pinteraction $^{6}$ & \multicolumn{2}{|c|}{0.41} & \multicolumn{2}{|c|}{0.84} \\
\hline \multicolumn{5}{|l|}{ Average daily amount ${ }^{7}$} \\
\hline Never $^{4}$ & 1.00 (ref) & 1.00 (ref) & 1.00 (ref) & 1.00 (ref) \\
\hline$\leq 1 \mathrm{cup} /$ day & $0.84(0.57-1.24)$ & $1.21(0.72-2.01)$ & $1.12(0.75-1.68)$ & $0.76(0.48-1.20)$ \\
\hline$>1$ to 2 cups/day & $1.26(0.87-1.83)$ & $0.78(0.47-1.30)$ & $0.97(0.64-1.45)$ & $1.14(0.73-1.79)$ \\
\hline$>2$ cups/day & $1.37(0.90-2.09)$ & $1.09(0.61-1.94)$ & $1.34(0.83-2.14)$ & $1.20(0.74-1.94)$ \\
\hline pinteraction $^{6}$ & \multicolumn{2}{|c|}{0.29} & \multicolumn{2}{|c|}{0.47} \\
\hline \multicolumn{5}{|l|}{ Duration of consumption ${ }^{7}$} \\
\hline Never $^{4}$ & 1.00 (ref) & 1.00 (ref) & 1.00 (ref) & 1.00 (ref) \\
\hline$<30$ years & $1.25(0.74-2.12)$ & $1.27(0.71-2.25)$ & $1.18(0.73-1.93)$ & $1.26(0.68-2.33)$ \\
\hline$\geq 30$ to $<40$ years & $1.31(0.77-2.20)$ & $0.67(0.36-1.23)$ & $0.70(0.39-1.27)$ & $1.27(0.70-2.31)$ \\
\hline$\geq 40$ to $<50$ years & $0.92(0.63-1.34)$ & $0.93(0.52-1.65)$ & $1.12(0.73-1.72)$ & $0.75(0.48-1.18)$ \\
\hline$\geq 50$ years & $1.24(0.80-1.91)$ & $1.26(0.65-2.44)$ & $1.41(0.87-2.27)$ & $1.08(0.63-1.86)$ \\
\hline pinteraction $^{6}$ & \multicolumn{2}{|c|}{0.47} & \multicolumn{2}{|c|}{0.13} \\
\hline \multicolumn{5}{|l|}{ Cumulative consumption ${ }^{7}$} \\
\hline Never $^{4}$ & 1.00 (ref) & 1.00 (ref) & 1.00 (ref) & 1.00 (ref) \\
\hline$\leq 40$ years, $\leq 2$ cups/day & $1.05(0.67-1.64)$ & $0.91(0.55-1.50)$ & $0.87(0.56-1.37)$ & $1.07(0.65-1.77)$ \\
\hline$\leq 40$ years, $>2$ cups/day & $1.98(0.98-3.98)$ & $1.12(0.49-2.54)$ & $1.14(0.56-2.33)$ & $2.32(0.92-5.89)$ \\
\hline$>40$ years, $\leq 2$ cups/day & $1.03(0.72-1.46)$ & $1.05(0.61-1.82)$ & $1.20(0.80-1.78)$ & $0.85(0.55-1.31)$ \\
\hline$>40$ years, $>2$ cups/day & $1.14(0.69-1.88)$ & $1.10(0.53-2.26)$ & $1.51(0.85-2.68)$ & $0.91(0.52-1.58)$ \\
\hline pinteraction $^{6}$ & \multicolumn{2}{|c|}{0.69} & \multicolumn{2}{|c|}{0.11} \\
\hline \multicolumn{5}{|c|}{$\begin{array}{l}\text { 1. Only includes participants with complete information on their black tea consumption } \\
\text { 2. Adjusted for age, respondent status, smoking (CSI), wine intake (never; weekly, not daily; daily), ethnicity (French Canadian; English } \\
\text { Canadian; other), median census tract income (low; medium; high), years of education }(<7 ; 7-<12 ; \geq 12) \text { and occupational exposure to } \\
\text { carcinogens (Never; non-substantial; substantial) } \\
\text { 3. Adjusted for same covariates as above, plus sex } \\
\text { 4. Participants were categorized as never consumers if they reported never consuming black tea at least once per week } \\
\text { 5: Participants were categorized as "weekly, not daily" consumers if they reported consuming black tea at least once per week but not nearly } \\
\text { every day }\end{array}$} \\
\hline $\begin{array}{l}\text { 6. pinteraction is the p-value for the } t \\
\text { 7. "Weekly, not daily" consumer }\end{array}$ & $\begin{array}{l}\text { interaction between th } \\
\text { ded }\end{array}$ & onsumption metric an & ither sex or smoking level & \\
\hline
\end{tabular}


